\title{
Enhanced aboveground biomass by increased precipitation in a central European grassland
}

Md Lokman Hossain ${ }^{1,2,3^{*}}$ (D) and Carl Beierkuhnlein ${ }^{2,4}$

\begin{abstract}
Background: Global climate change is projected to increase temperature and alter precipitation pattern, which could affect grassland ecosystem. Long-term observation at a field experiment can be a powerful approach to explore the impacts of climate change on biomass productivity in grassland. In attempting to understand how climatic variability regulates biomass productivity, we analyzed long-term records of temperature and precipitation to examine how variation of temperature and precipitation across 19 years affect biomass productivity.

Methods: We established the experiment with 64 plots in two blocks and planted 31 species in 30 different mixtures. We harvested aboveground biomass twice a year, sorted biomass by functional groups, and weighed dry biomass. The site was mown after each harvest. We did not apply any fertilizer and water. Using linear regression model, we examined the influences of growing season temperature and precipitation on biomass productivity.
\end{abstract}

Results: The results showed that aboveground biomass productivity in September and annual were significantly increased in post-drought (2003-2015). The relationships of aboveground biomass productivity with growing season precipitation were significantly positive. The results showed that aboveground biomass productivity in June and annual were sensitive to growing season temperature. The relationships of aboveground biomass productivity of the functional group of grasses with early growing season temperature were significantly negative. Early growing season precipitation had a significant positive effect on aboveground biomass productivity of the functional groups of grasses and legumes. Post-drought aboveground biomass productivity of the functional groups of grasses in June and September were declined, whereas legumes significantly increased, which suggests that the role of dominant grasses may shift by legumes with global climate change.

Conclusions: Our results highlight that early and late growing temperature and precipitation variability may reduce the aboveground biomass productivity in grassland. Our study implies that the combination of several functional groups is essential for the maintenance of stable productivity in temperate grassland ecosystem.

Keywords: Aboveground biomass, BIODEPTH experiment, Climate change, Functional groups, Grassland biodiversity, Hay meadow, Precipitation variability, Temperate grassland, Temperature variability

\section{Introduction}

Studying the effects of climate change on plant communities is an important research goal in ecology and gaining increased importance under global warming. Several experimental studies (Tilman and Downing 1994; Grime et al. 2000; Jentsch et al. 2007; Wang et al. 2007; Bloor et al.

\footnotetext{
* Correspondence: lokmanbbd@gmail.com

'Department of Geography, Hong Kong Baptist University, 15 Baptist University Road, Kowloon Tong, Hong Kong

${ }^{2}$ Global Change Ecology, International Elite Study Programme, Faculty of

Biology, Chemistry and Earth Sciences, University of Bayreuth,

Universitätsstraße 30, 95440 Bayreuth, Germany

Full list of author information is available at the end of the article
}

2010; Butof et al. 2012; Walter et al. 2012; Backhaus et al. 2014; Urbina et al. 2014; Gargallo-Garriga et al. 2015; Gellesch et al. 2015; Isbell et al. 2015; Ludewig et al. 2015; Malyshev et al. 2015) have investigated the effects of climate change on plant productivity. A range of studies (Knapp et al. 2008; Beierkuhnlein et al. 2011; Kreyling et al. 2011b; Weißhuhn et al. 2011) have revealed that the functioning of grassland species is affected by drought.

Precipitation is one of the most influential abiotic factors for plant productivity in almost all terrestrial ecosystems (Lieth 1975; Webb et al. 1986; Sala et al. 1988; Huxman et al. 2004). Several studies (Beierkuhnlein et 
al. 2011; Jentsch et al. 2011; Walter et al. 2012) have revealed that the magnitude of the rainfall events and their seasonal frequency are important for temperate grassland productivity. IPCC scenarios have shown that precipitation pattern will be altered in the course of climate change (IPCC 2007). According to regional climate change projections, Germany will experience higher temperature and an increasing risk for summer droughts in the late twenty-first century (Görgen et al. 2010).

Plant community ecologists have long been interested in how plant functional groups (grasses, herbs, and legumes) influence primary productivity of an ecosystem. The mass ratio hypothesis (Grime 1998) predicts that the effects of species of an ecosystem are dependent on species functional groups. Several plant functional groups are important for above- and belowground biomass production and can increases over $300 \%$ more biomass than monoculture species (Tilman et al. 2001) and have a complementarity effect (Huston et al. 2000; McLaren and Turkington 2010). Shallow- and fibrous-rooted grasses have suffered from lower precipitation and higher temperature (Fay et al. 2003; Morecroft et al. 2004; Grant et al. 2017); however, deep-rooted herbs and legumes can maintain productivity (Sage and Kubien 2007; Kakani et al. 2008). Some studies (Grime et al. 2000; Weißhuhn et al. 2011; Craine et al. 2012; Jentsch et al. 2014) have revealed that growing season temperature is not the driving factor; rather, growing season precipitation (Duncan and Woodmansee 1975; Fay et al. 2003) regulated the grassland productivity. However, it is not clear whether early or late growing season temperature and precipitation have significant influence on aboveground biomass productivity.

Hay meadows are one of the most species-rich terrestrial ecosystems in Europe (Veen et al. 2009; García-Feced et al. 2015) and managed for conservation purposes (Dahlström et al. 2013). Hay meadows are permanent ecosystem and need attention in the face of climate change. A range of experiments (Beierkuhnlein et al. 2011; Jentsch et al. 2011; Kreyling et al. 2011a; Backhaus et al. 2014; Urbina et al. 2014; Gargallo-Garriga et al. 2015; Gellesch et al. 2015; Malyshev et al. 2015) in Germany have conducted to understand the effect of climate change on hay meadows and grassland. BIODEPTH (BIODiversity and Ecological Processes in Terrestrial Herbaceous Ecosystems) is such an experiment, which was established in 1996 at eight sites across Europe with a view to assessing plant diversity and primary productivity (Hector et al. 1999). One site of this experiment has been established at Lindenhof, Bayreuth, Germany, by the Department of Biogeography, University of Bayreuth.

The primary objectives of our study are:
1. To investigate the response of aboveground biomass production of hay meadow to temperature and precipitation variability

2. To determine whether several functional groups buffer adverse effects of increased growing season temperature and precipitation or amplify the dominance pattern on biomass production

We tested the following hypotheses:

1. Higher growing season temperature negatively affects the aboveground biomass of hay meadow

2. Growing season precipitation variability adversely affects the aboveground biomass of hay meadow

3. Dominance patterns of functional groups explain variance in aboveground biomass production

4. Several functional groups buffer adverse effects of increased growing season temperature and precipitation variability

\section{Materials and methods \\ Study site}

The experiment was carried out at the German site of the former BIODEPTH project. The study site is situated at Lindenhof, Bayreuth $\left(49^{\circ} 55^{\prime} \mathrm{N}, 11^{\circ} 35^{\prime} \mathrm{E}\right.$, altitude $355 \mathrm{~m}$ a.s.l.). The experimental layout was based on BIODEPTH concept of identical design at eight sites across Europe (Hector et al. 1999). The study site's annual precipitation is $709 \mathrm{~mm}$, and average annual temperature is $8.2^{\circ} \mathrm{C}$. The experiment was established on a former arable land, where the soil consists of keuper marl from trias, and the soil type is brown soil-pseudogley with variable mixture.

\section{Soil characteristics}

The soil was a loamy to sandy stagnic gleysol with $\mathrm{pH}$ $\left(\mathrm{CaCl}_{2}\right)=5.65 \pm 0.20$. Soil carbon content was $0.78 \pm 0.06 \%$ in 1996 and $0.77 \pm 0.10 \%$ in 2002. Soil nitrogen content was $0.08 \pm 0.01 \%$ in 1996 and $0.13 \pm 0.01 \%$ in 2002 (Kreyling et al. 2011a). In 2002, no differences were observed between two blocks in case of $\mathrm{C} / \mathrm{N}$ ratio $(P=0.446)$, nitrogen contents $(P=0.640)$, and carbon contents $(P=0.373)$ (Kreyling et al. 2011a).

\section{Experimental design}

In autumn 1995, aboveground biomass was removed and the ground was deeply plowed. In early spring 1996, the previous seed banks were eliminated through in situ steam sterilization of soil. Initial experimental design during 1996-1998 consists of two blocks, and each block consists of 32 plots (Fig. 1). Each plot size is 2 $\mathrm{m} \times 2 \mathrm{~m}$ quadrats. Seeds of 31 grassland species 


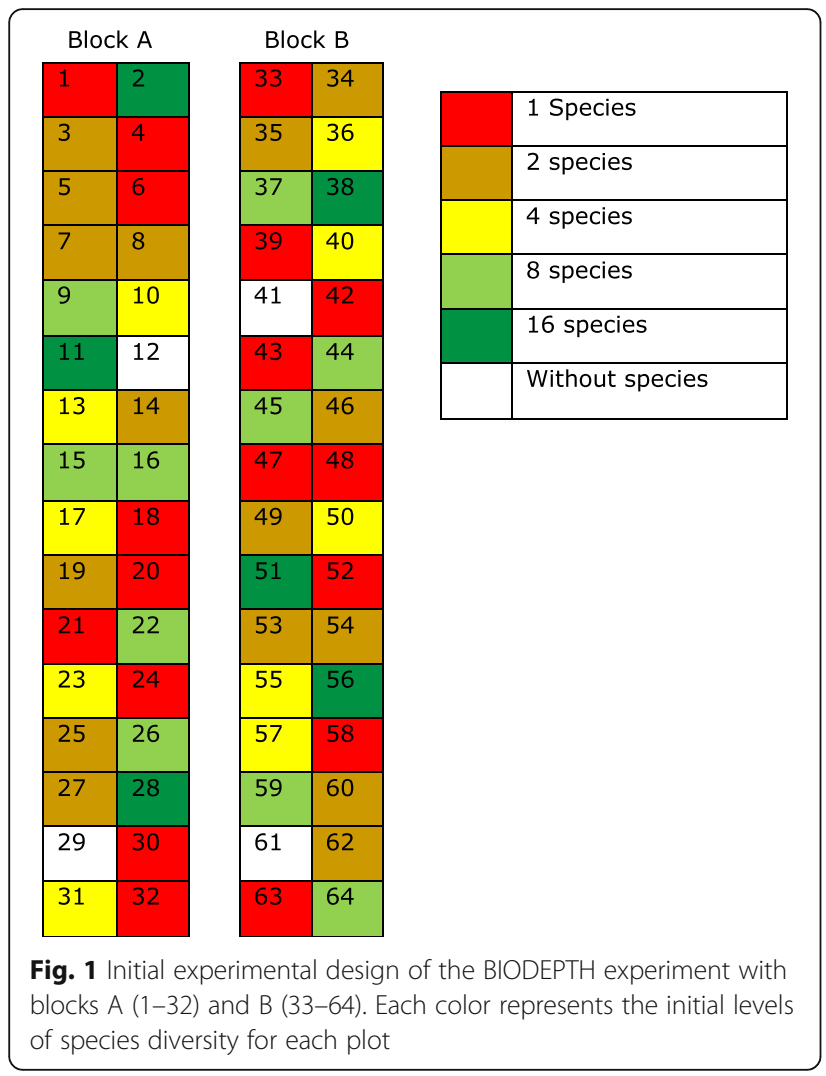

(functional groups of herbs, grasses, and legumes) were collected and assembled by independent random draws. However, it was ensured that all multi-species communities contained grasses. Each diversity level was replicated with different mixtures, and total 30 mixtures of communities were taken. Each block contained 30 mixtures; thus, each mixture represented twice. Therefore, 60 plots were allocated with 30 mixtures. No seeds were allocated in four plots (Fig. 1).

\section{Species pool studied}

Thirty-one traditional grassland species were allocated with different mixtures at the experiment in 1996 (Appendix). Since September 1998, no weeding was done, so species from neighboring plots and surrounding vegetation intruded.

\section{Management of experimental site}

During 1996-1998, non-target species were weeded to avoid the competition with the target species. Since 1999, the succession was allowed to take place as weeding was stopped after final harvest in September 1998. No fertilization and watering were done during the whole study period. After each harvest of aboveground biomass, field site was mown. Therefore, mowing was done twice a year (June and September). The paths between the plots were not mown since 1998. This allows the chance of other species to invade the surrounding plots. The field site was protected by the fence to avoid grazing by herbivores. Unfortunately, in August 2001, some sheep entered into the site and destroyed biomass partly. That is why, the aboveground biomass of few plots in September 2001 reduced.

\section{Data collection}

\section{Aboveground biomass harvest}

Aboveground biomass was harvested twice (June and September) a year by two samples of $20 \mathrm{~cm} \times 50 \mathrm{~cm}$ within the central square meter $(1 \mathrm{~m} \times 1 \mathrm{~m})$ of each plot. At each harvest, vegetation was cut $5 \mathrm{~cm}$ above the ground. Each sample biomass was collected in the polythene bag. Biomass was sorted by functional groups. Sorted biomass was taken in a paper bag and then dried at $80^{\circ} \mathrm{C}$ for $24 \mathrm{~h}$ and finally weighed in the laboratory of Department of Biogeography at the University of Bayreuth.

\section{Temperature and precipitation}

Daily temperature and precipitation data across 19 years were obtained from the German Weather Service station in Bayreuth.

\section{Data handling and statistical analyses}

All statistical analyses were performed using $\mathrm{R}$ statistical software. We used simple linear regression based on 19 years of dataset.

\section{Results}

\section{Aboveground biomass production}

The results showed that aboveground biomass in June decreased and in September and annual sum increased across 19 years (Fig. 2a). Mean biomass in June $\left(386 \mathrm{~g} \mathrm{~m}^{-2}\right)$ was two and half times higher than that in September $\left(153 \mathrm{~g} \mathrm{~m}^{-2}\right)$. The highest aboveground biomass in June $\left(484 \mathrm{~g} \mathrm{~m}^{-2}\right)$ was recorded in the year 2002 and in September $\left(301 \mathrm{~g} \mathrm{~m}^{-2}\right)$ in 2011. The results also revealed that pre-drought biomass in June was increased, while in September and annual sum decreased (Fig. 2b). Post-drought aboveground biomass in September and the annual sum increased significantly (September: $R^{2}=0.29 ; \quad P=0.05$, annual: $R^{2}=0.39 ; P=0.02$ ) across 13 years (Fig. 2 c).

\section{Biomass responses to temperature variability}

Aboveground biomass productivity in June $\left(R^{2}=0.272\right.$; $P=0.021$, Fig. 3a) and annual $\left(R^{2}=0.379 ; P=0.004\right.$; 


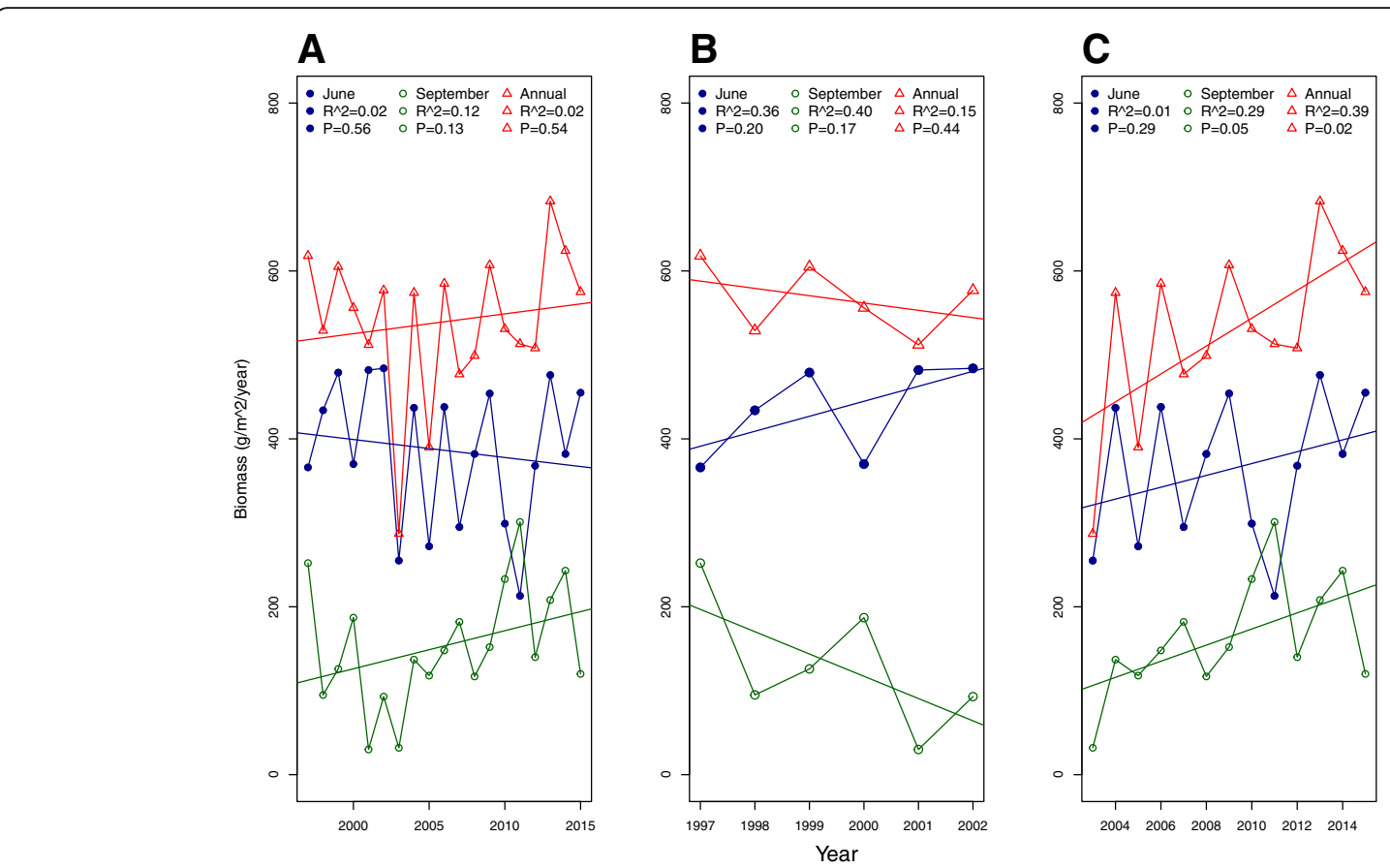

Fig. 2 Variation of aboveground biomass production in June, September, and annual across 19 years (a), pre-drought (1997-2002) (b), and post-drought (2003-2015) (c)
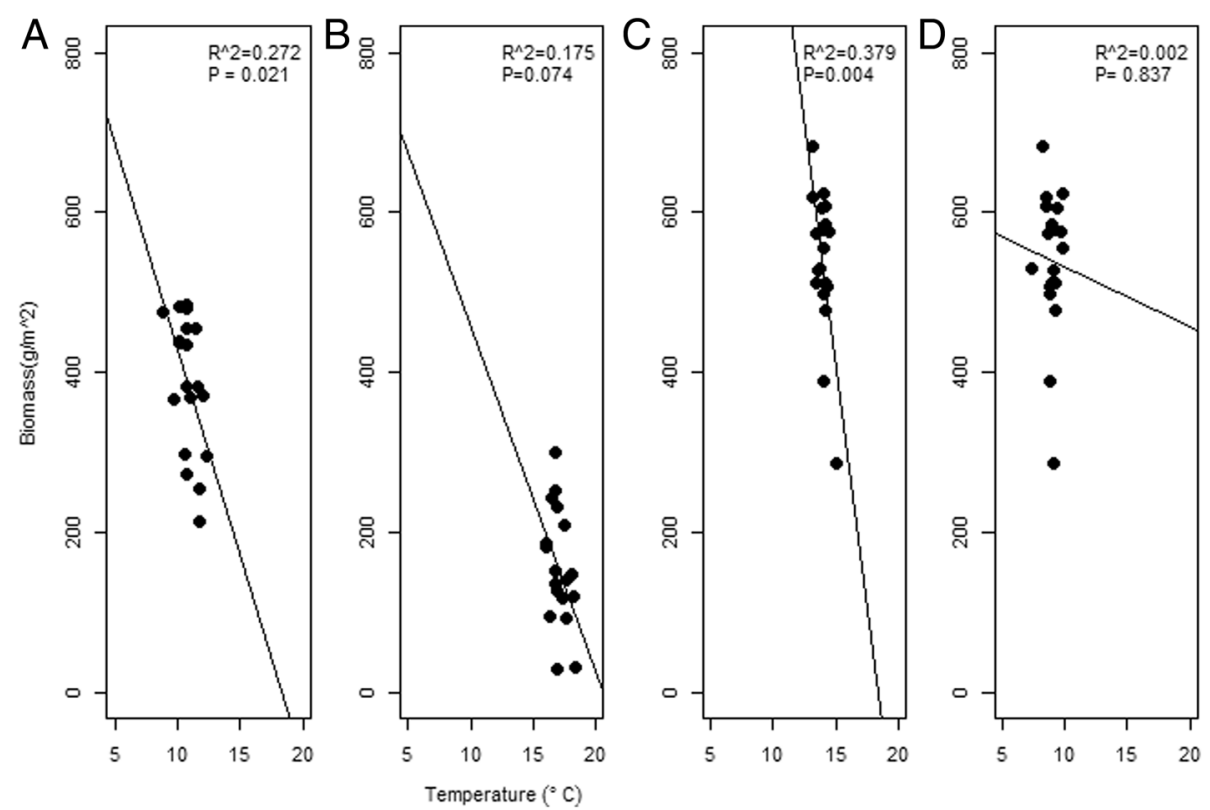

Fig. 3 Response of aboveground biomass productivity to temperature variability for the study period 1997-2015. Relationships of aboveground biomass in June with growing season (March-June) temperature (a), biomass in September with growing season (June-September) temperature (b), annual biomass with growing season (March-September) temperature (c), and annual biomass with annual mean temperature (d) 

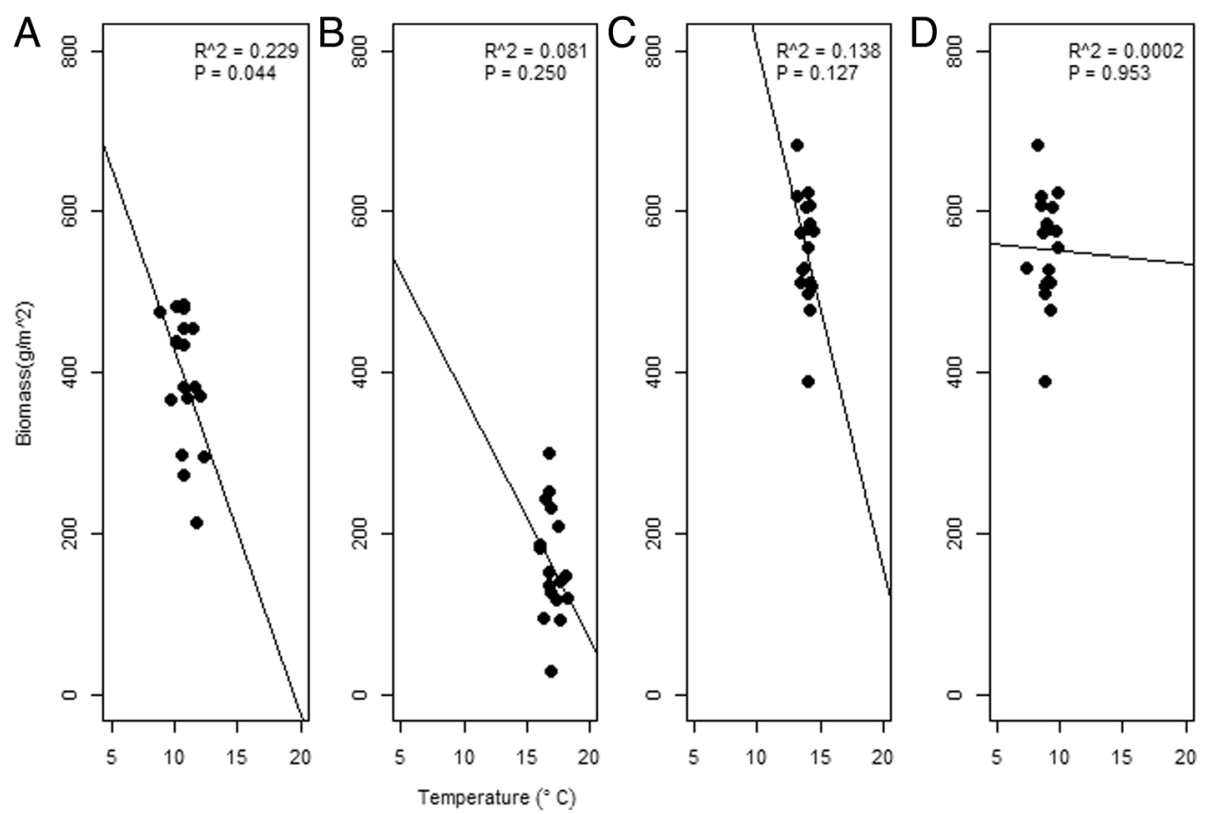

Fig. 4 Response of aboveground biomass productivity to temperature variability for the study period 1997-2015, excluding the extreme event 2003. Relationships of aboveground biomass in June with growing season (March-June) temperature (a), biomass in September with growing season (June-September) temperature (b), annual biomass with growing season (March-September) temperature (c), and annual biomass with annual mean temperature (d)

Fig. 3c) significantly declined with growing season temperature increase. However, the relationships of biomass productivity in September with growing season temperature $\left(R^{2}=0.175 ; P=0.074\right.$, Fig. $\left.3 \mathrm{~b}\right)$ and of annual biomass with annual mean temperature $\left(R^{2}=0.002 ; P=\right.$ 0.837 , Fig. $3 \mathrm{~d}$ ) were not significant.

\section{Biomass responses to temperature variability excluding the extreme event}

The results showed that aboveground biomass in June significantly decreased with growing season temperature increase $\left(R^{2}=0.229 ; P=0.044\right.$, Fig. 4a). However, the relationships of aboveground biomass with temperature were not improved by excluding the extreme event. The relationships of biomass in September with growing season temperature $\left(R^{2}=0.081 ; P=0.250\right.$, Fig. $\left.4 \mathrm{~b}\right)$, in annual with growing season temperature (Fig. $4 \mathrm{c}$ ), and in annual with mean annual temperature (Fig. $4 \mathrm{~d}$ ) were not significant.

\section{Biomass responses to precipitation variability}

The relationships of aboveground biomass in June with growing season (March-June) precipitation and in September with growing season (June-September) precipitation were significant (June biomass: $R^{2}=0.335 ; P=0.009$, Fig. 5a; September biomass: $R^{2}=0.533 ; P<0.001$, Fig. $5 \mathrm{~b}$ ). However, the relationships of annual biomass with growing season (March-September) precipitation and annual biomass with annual precipitation were not significant (Fig. 5c, d).

\section{Biomass responses to precipitation variability excluding the extreme event}

Excluding the extreme event, the results showed that the relationships of aboveground biomass in June with growing season (March-June) precipitation and biomass in September with growing season (JuneSeptember) precipitation were significant (June: $R^{2}=$ $0.285 ; P=0.022$, Fig. 6a, September: $R^{2}=0.453 ; P=$ 0.002 , Fig. $6 \mathrm{~b})$. Interestingly, annual biomass productivity responded negatively with increasing annual precipitation, but it was not significant (Fig. 6d). Growing season (March-September) precipitation had no effects on annual biomass (Fig. 6c).

\section{Performance of functional groups in pre-drought and post-drought}

The results showed that aboveground biomass productivity of the functional groups of grasses and legumes in June increased significantly in pre-drought (grasses: $R^{2}=$ $0.75 ; P=0.02$, Fig. 7a; legumes: $R^{2}=0.68 ; P=0.04$, Fig. 7a). Post-drought legumes biomass in June $\left(R^{2}=0.65 ; P<0.01\right.$, 

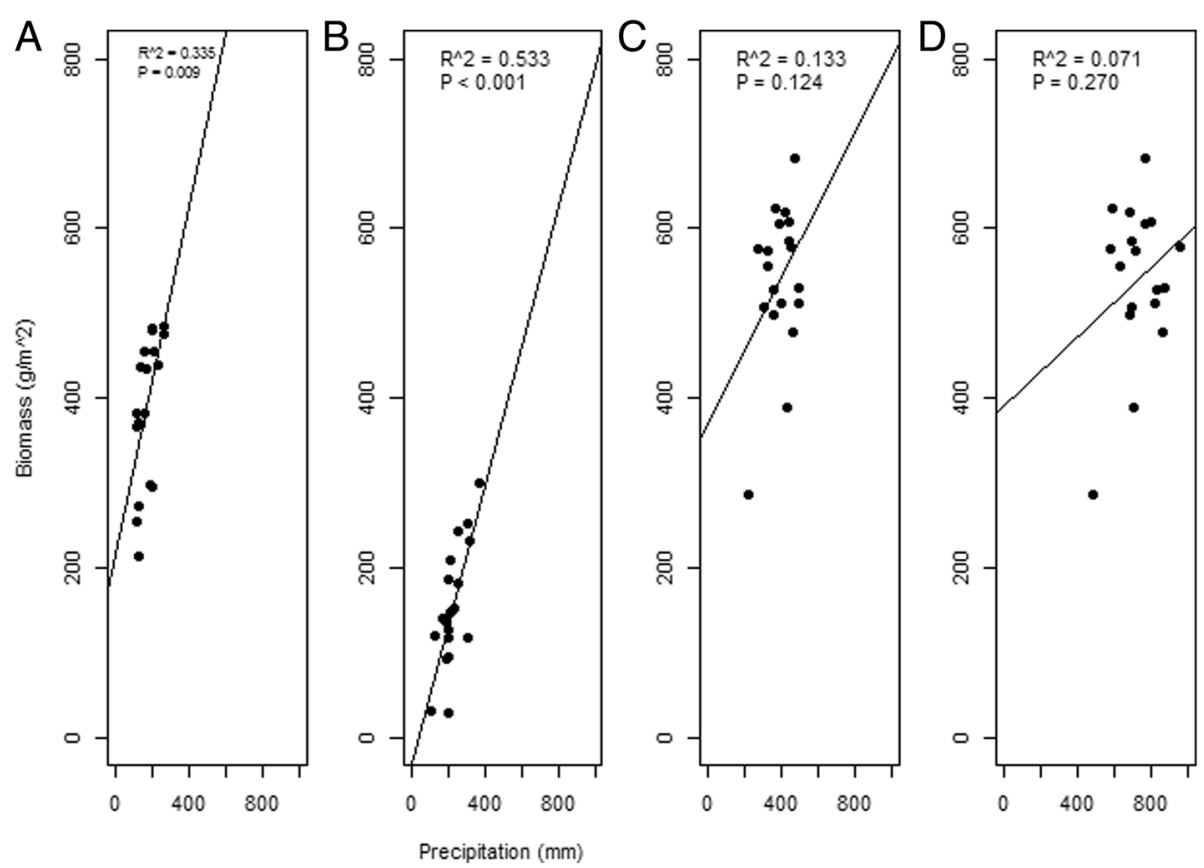

Fig. 5 Response of aboveground biomass productivity to precipitation variability for the study period 1997-2015. Relationships of aboveground biomass in June with growing season (March-June) precipitation (a), biomass in September with growing season (June-September) precipitation (b), annual biomass with growing season (March-September) precipitation (c), and annual biomass with annual precipitation (d)
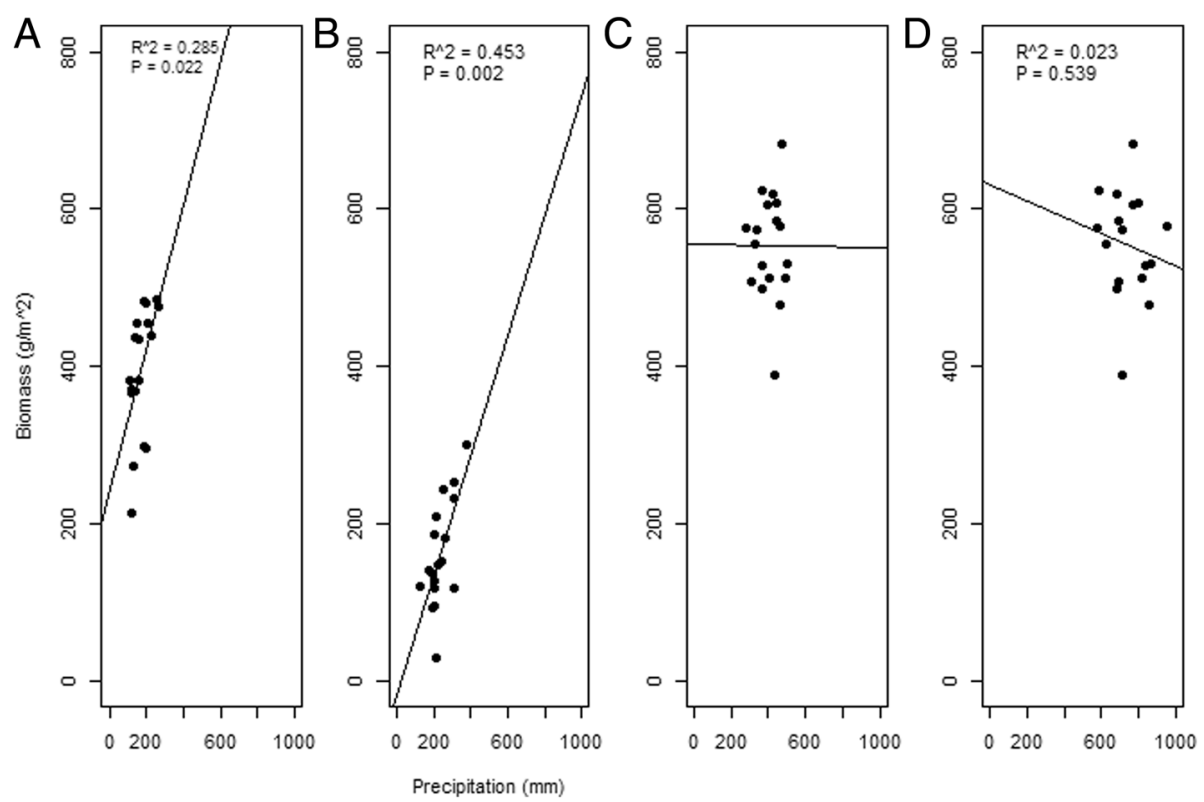

Fig. 6 Response of aboveground biomass productivity to precipitation variability for the study period 1997-2015, excluding the extreme event 2003. Relationships of aboveground biomass in June with growing season (March-June) precipitation (a), biomass in September with growing season (June-September) precipitation (b), annual biomass with growing season (March-September) precipitation (c), and annual biomass with annual precipitation $(\mathbf{d})$ 


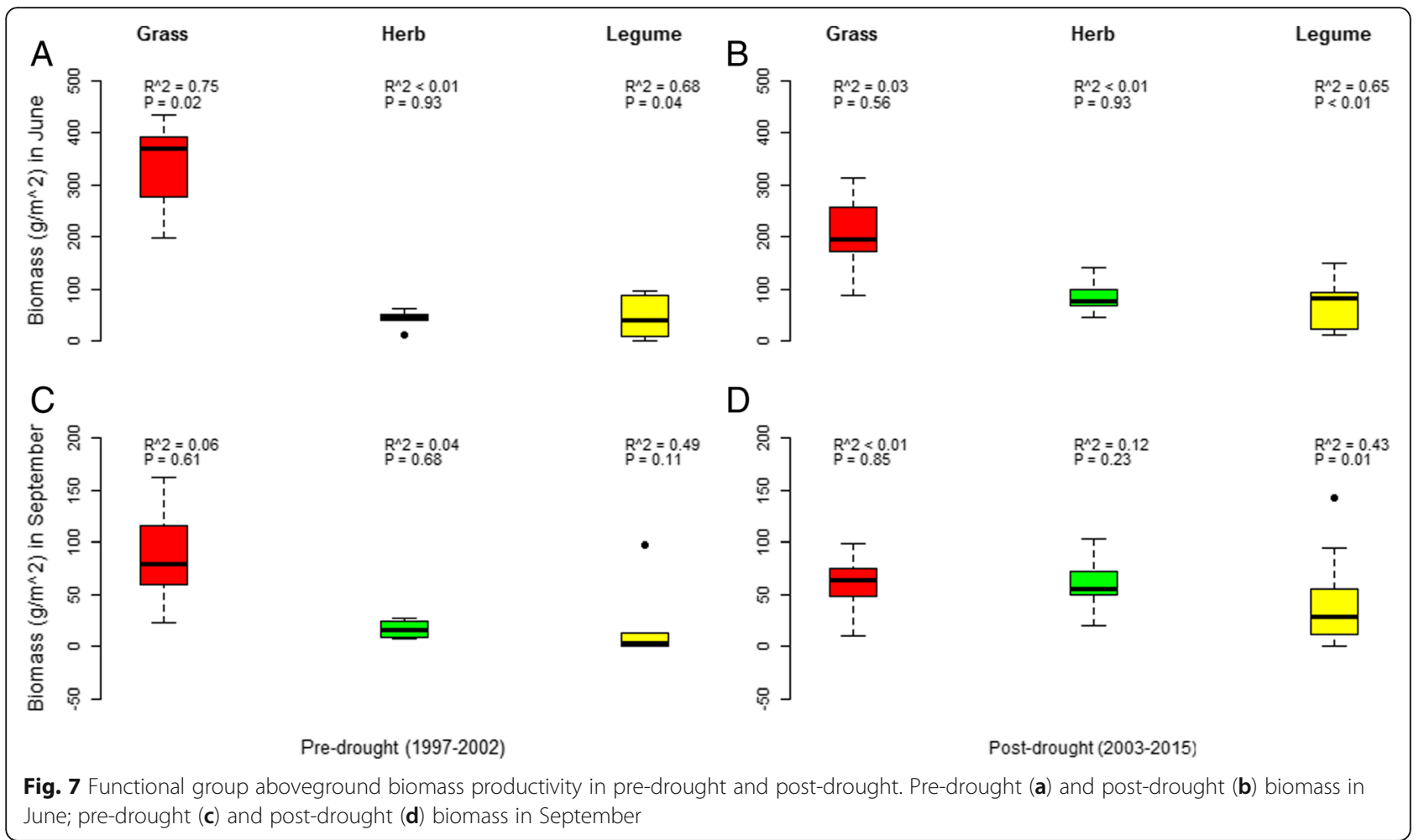

Fig. 7b) and in September $\left(R^{2}=0.43 ; P=0.01\right.$, Fig. $\left.7 d\right)$ also significantly increased.

\section{Functional group response to the early growing and late growing season temperature}

Early growing season temperature in September had a significant $\left(R^{2}=0.25 ; P=0.02\right.$, Fig. $\left.8 \mathrm{c}\right)$ negative effect on aboveground biomass productivity of the functional group of grasses. With the increase of late growing season temperature, aboveground biomass of the functional group of herbs in June $\left(R^{2}=0.44 ; P=0.001\right.$, Fig. $\left.8 f\right)$ and September $\left(R^{2}=0.30 ; P=0.01\right.$, Fig. $\left.8 \mathrm{~h}\right)$ harvests significantly decreased. The relationships of aboveground biomass of the functional group of legumes with late growing season temperature in June were significantly negative $\left(R^{2}=0.23 ; P=0.03\right.$, Fig. $\left.8 \mathrm{j}\right)$.

\section{Functional group response to the early growing and late growing season precipitation}

The relationships of aboveground biomass productivity of the functional group of grasses with early growing season precipitation in June were significantly positive $\left(R^{2}=0.52 ; P<0.001\right.$, Fig. 9a). Early growing season precipitation in September had a significant positive effect on aboveground biomass productivity of the functional group of legumes $\left(R^{2}=0.37 ; P<0.001\right.$, Fig. 9k). Aboveground biomass productivity of the functional group of herbs did not show any significant relationships with early and late growing season precipitation (Fig. 9e, f, g, h).

\section{Discussion}

\section{Aboveground biomass productivity}

Despite opposite trends of aboveground biomass productivity in June and September harvests, there was an increasing trend of annual aboveground biomass productivity across 19 years. Aboveground biomass productivity was not significantly responded in pre-drought (1997-2002). However, aboveground biomass productivity in September and annual sum were significantly increased in post-drought (20032015) period. Our findings are consistent with Jentsch et al. (2011), who found that annual primary productivity was not declined to drought, and Grant et al. (2017) who showed that productivity increased by $12 \%$ due to increased warming.

\section{Biomass responses to temperature variability}

Our results showed a significant decrease in aboveground biomass in June and annual sum with the 
A

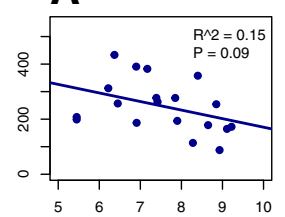

E
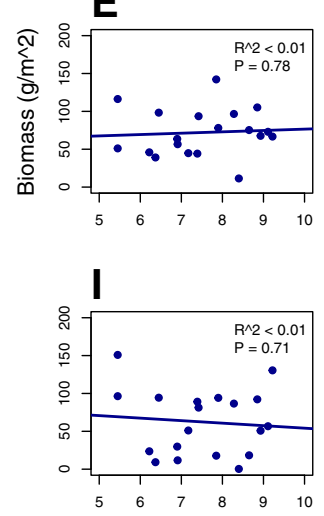

B
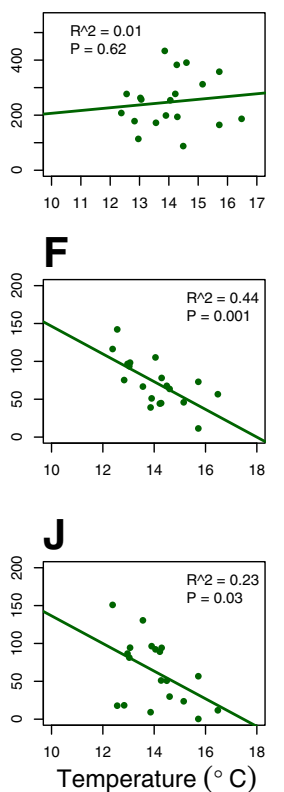

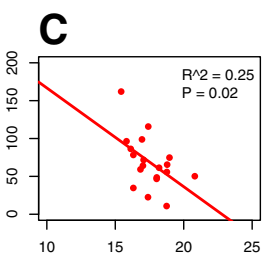

D

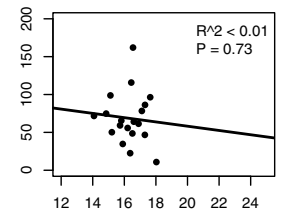

G

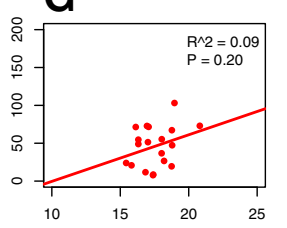

H
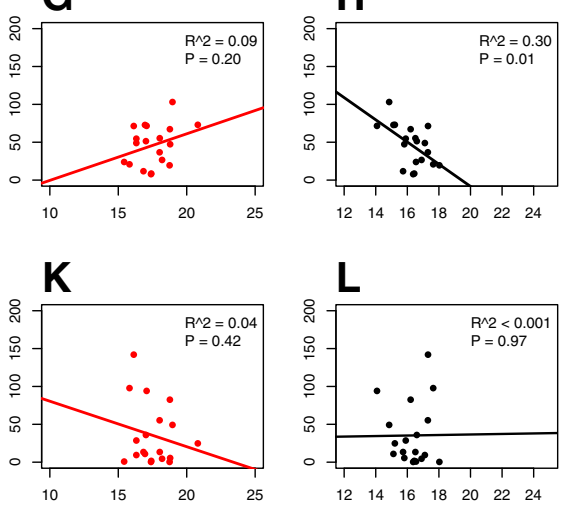

Fig. 8 Response of functional group aboveground biomass productivity to early and late growing temperature in June and September. Relationships of aboveground biomass productivity of the functional group of grasses with early growing season (16 March-30 April) temperature in June (a), late growing season (01 May-15 June) temperature in June (b), early growing season (16 June-31 July) temperature in September (c), and late growing season (01 August-15 September) temperature in September (d) harvests. Relationships of aboveground biomass productivity of the functional group of herbs with early growing season temperature in June (e), late growing season temperature in June (f), early growing season temperature in September $(\mathbf{g})$, and late growing season temperature September (h) harvests. Relationships of aboveground biomass productivity of the functional group of legumes with early growing season temperature in June (i), late growing season temperature in June (j), early growing season temperature in September (k), and late growing season temperature September (I)

increase of growing season temperature (Fig. 3a, c), which is consistent with Weißhuhn et al. (2011) and Jentsch et al. (2014) who found that biomass production decline with warming. Grime et al. (2000) found that grassland biomass of a 5-year experiment was declined by winter heating, and Sternberg et al. (1999) and Kahmen et al. (2005) showed that experimental drought events reduce biomass productivity which is also consistent with our findings. Our results are in accordance with the hypothesis stating that growing season temperature increase has negative effects on aboveground biomass productivity. However, our findings are inconsistent with Beierkuhnlein et al. (2011) and Ma et al. (2017) who found that warming has no or very limited influence on biomass productivity. Two recent studies revealed that warming significantly increase the biomass (Chen et al. 2017) and growing season air and soil warming has also positive impacts on aboveground biomass productivity on the Qinghai-Tibetan Plateau (Guo et al. 2018). A growing body of evidence suggests that higher growing season temperature can lower biomass productivity by reducing water availability and limiting photosynthesis (Knapp et al. 2008) and increasing evapotranspiration (Reichstein et al. 2006; De Boeck et al. 2011). Higher growing season temperature can generate physiological stress (Crafts-Brandner and Salvucci 2002) and stimulate root growth instead of shoot growth (Asseng et al. 1998).

\section{Biomass response to precipitation variability}

Like many other studies (Lauenroth and Sala 1992; Sternberg et al. 1999; Grime et al. 2000; Kahmen et al. 2005; La Pierre et al. 2016), our results showed a significant increase in aboveground biomass productivity in June and September with the increase of growing season precipitation (Fig. 5a, b). Our results are consistent with Walter et al. (2012) who found that aboveground biomass altered with precipitation variability, Grant et al. (2014) who observed that high intra-annual precipitation variability decrease biomass production compared to low intra-annual 

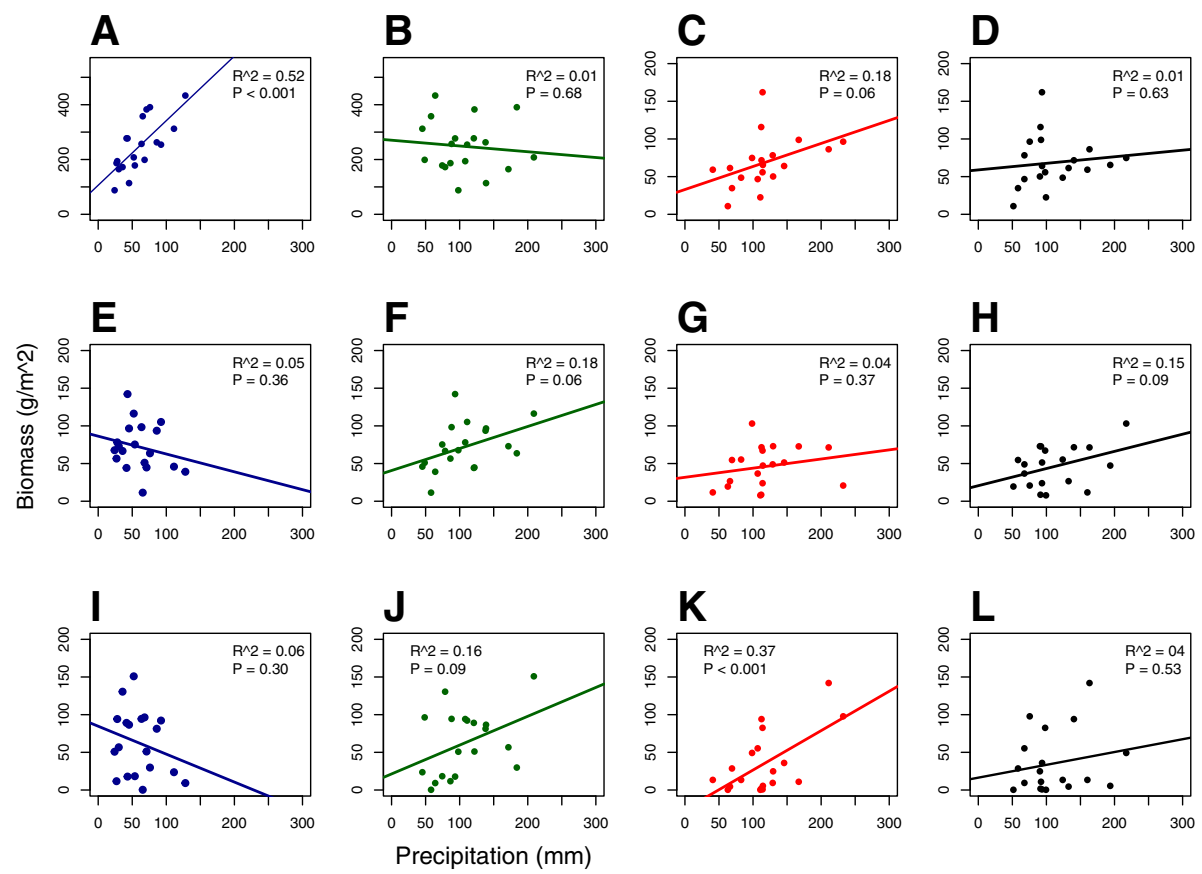

Fig. 9 Response of functional group aboveground biomass productivity to early and late growing precipitation in June and September. Relationships of aboveground biomass productivity of the functional group of grasses with early growing season precipitation in June (a), late growing season precipitation in June (b), early growing season precipitation in September (c), and late growing season precipitation in September (d) harvests. Relationships of aboveground biomass productivity of the functional group of herbs with early growing precipitation in June (e), late growing precipitation in June (f), early growing precipitation in September (g), and late growing precipitation September (h) harvests. Relationships of aboveground biomass productivity of the functional group of legumes with early growing precipitation in June (i), late growing precipitation in June (j), early growing precipitation in September (k), and late growing precipitation September (I)

precipitation variability, and $\mathrm{Ru}$ et al. (2017) who found that precipitation reduction severely affect plant productivity. Apart from European grassland, Lauenroth and Sala (1992) found a positive correlation between aboveground net primary production and precipitation using a 52-year dataset in North America, and Ma et al. (2017) found that higher precipitation increase $17.5 \%$ community biomass in alpine grassland on the Tibetan Plateau. Our results are in accordance with the hypothesis stating that growing season precipitation increase has positive effects on aboveground biomass production. However, our findings are inconsistent with Fay et al. (2003) who revealed that aboveground biomass production was not responded or negatively responded with increasing precipitation.

\section{Performance of functional groups to temperature and precipitation variability}

The significant increase of aboveground biomass productivity of the functional group of legumes in post-drought (Fig. $7 \mathrm{~b}, \mathrm{~d}$ ) in our study may be the reason for fertilization effects of nitrogen-fixing legumes. Our results coincide with Huston et al. (2000), who commented on an article of Hector et al. (1999) and showed that a single species of legume has strong positive effects on aboveground biomass productivity in eight sites of BIODEPTH experiment across Europe. The increase of total aboveground biomass productivity across 19 years could possibly be due to the complementarity effect of the functional groups of grasses, herbs, and legumes, i.e., reduction of grasses biomass compensated by herbs and legumes. Chen et al. (2017) found that legumes biomass increased by $27.6 \%$ in warming treatment which supports our findings that legumes in post-drought increased significantly in June and September harvests. Our results showed that the aboveground biomass productivity of the functional group of grasses declined in post-drought (Fig. $7 \mathrm{~b}, \mathrm{~d}$ ), which are consistent with the findings of Fay et al. (2003), Morecroft et al. (2004), and Grant et al. (2017). 
Early growing season and late growing season temperature influenced aboveground biomass productivity of the functional groups of grasses, herbs, and legumes across 19 years. The relationships of aboveground biomass productivity of the functional group of grasses with early growing season temperature in September were significantly negative (Fig. 8c), which is consistent with Guo et al. (2018), who found that pre-season warming reduces aboveground biomass productivity. Late growing season temperature has also significant negative effects on aboveground biomass productivity of the functional groups of herbs (Fig. 8f, h) and legumes (Fig. 8 j).

Aboveground biomass productivity of the functional groups of grasses in June (Fig. 9a) and legumes in September (Fig. 9k) were significantly increased with the increase of early growing season precipitation. Our findings are consistent with Chelli et al. (2016) who found that early season precipitation has a positive response to aboveground net primary productivity and Zavaleta et al. (2003) who found that precipitation timing influences biomass productivity in Mediterranean grasslands. Several studies (Suttle et al. 2007; Chelli et al. 2016, and $\mathrm{Ru}$ et al. 2017) have revealed that early growing season precipitation influences plant productivity and favors plant growth, which coincides with our results.

Shallow- and fibrous-rooted grasses uptake water from upper part of the soil profile, and hence, the increase of early growing season precipitation means availability of soil moisture in topsoil which can be utilized by grasses. Likely reasons for varying behavior of grasses, herbs, and legumes to early growing season precipitation may be due to plant root structure, adaptation strategies, the presence of nodules, root depth, etc. The results of functional groups biomass also revealed that declining grasses biomass was compensated by herbs and legumes which is consistent with McLaren and Turkington (2010) who found that removal of one functional group compensated by other functional groups in terms of biomass recovery and Tilman et al. (2001) who explored that several functional groups produce $300 \%$ higher biomass compared to single functional group.

Growing season temperature and precipitation yielded three key findings: (1) early growing season temperature has significant negative effects on aboveground biomass productivity of the functional group of grasses in September, (2) late growing season temperature has significant negative effects on aboveground biomass productivity of the functional groups of herbs and legumes in June harvest, and (3) early growing season precipitation has significant positive effects on the aboveground biomass productivity of the functional groups of grasses in June and legumes in September. This apparent discrepancy is probably because it is not early or late growing season precipitation (Duncan and Woodmansee 1975; Fay et al. 2003), rather late growing season temperature is a strong limiting factor in aboveground biomass productivity (Grime et al. 2000; Weißhuhn et al. 2011; Craine et al. 2012; Jentsch et al. 2014) of herbs and legumes. These results highlight the importance of different functional groups for grassland ecosystem functioning in the face of climate change.

\section{Conclusion}

European hay meadows are sensitive to global climate change. The drought has significant effects on aboveground biomass productivity in a long-run experiment. Our study shows that aboveground biomass productivity in September and annual significantly increase in post-drought, but decrease in the pre-drought period. We demonstrate that environmental drivers (temperature and precipitation) are important in grassland productivity. The responses of aboveground biomass to growing season temperature and precipitation are different. For instance, aboveground biomass in June declines significantly with growing season temperature, whereas aboveground biomass in June and September increases with growing season precipitation. Our study provides new empirical evidence that the relationships of dominant grasses with early growing season temperature in September are significantly negative and with early growing season precipitation in June and September are significantly positive. Aboveground biomass productivity of the functional group of herbs is sensitive to late growing season temperature. Early growing season precipitation has strong positive effects on the aboveground biomass productivity of the functional group of legumes in September. Our study suggests that the presence of several functional groups is vital in sustaining grassland productivity and ecosystem functioning. Incorporating a more thorough understanding of how growing season temperature and precipitation affect aboveground biomass productivity is necessary to advance our understanding of grassland biomass productivity dynamics in the face of climate change. 


\section{Appendix}

Table 1 List of species planted in 1996. Each column indicates number of species, species name, and plots where species are planted

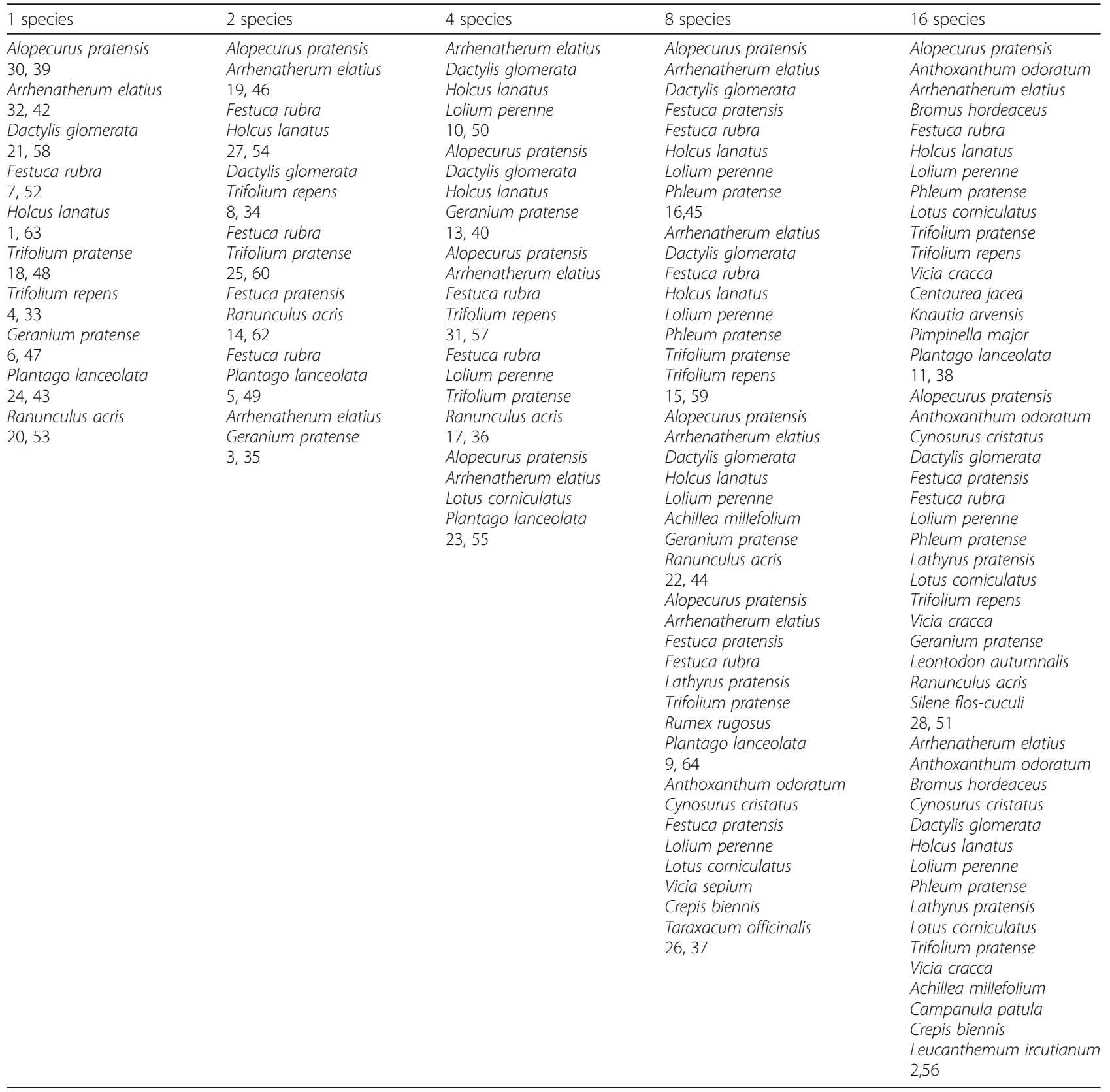




\section{Acknowledgements}

Our first and foremost thanks go to the researchers who collected data year after year at this long-term study site. We are thankful to the reviewers for the constructive comments on the manuscript. We are grateful to the Department of Biogeography, University of Bayreuth, for maintaining the experimental site and providing the datasets. We extend our gratitude to German Weather Service Station in Bayreuth for sharing the climate datasets. We are also thankful to Mr. Reinhold Stahlmann, Department of Biogeography, University of Bayreuth, for his assistance during data collection.

\section{Data accessibility}

The original datasets have been preserved at the Department of Biogeography, University of Bayreuth, Germany.

\section{Funding}

The BIODEPTH project was funded by the European Commission within the Framework IV Environment and Climate program (ENV-CT95-0008) and coordinated by Prof. Dr. Carl Beierkuhnlein, Department of Biogeography, University of Bayreuth, Germany.

\section{Availability of data and materials}

The authors declare that the data and materials presented in this manuscript can be made publicly available by Springer Open as per the editorial policy.

\section{Authors' contributions}

$\mathrm{CB}$ designed the experiment, supervised the data collection, monitored the experiment, preserved the dataset, and edited the manuscript, and M.L. Hossain designed the protocol, collected the samples for two growing seasons, analyzed the data, prepared all figures, and wrote the manuscript. Both authors contributed to the writing of the manuscript, read and approved the final manuscript. This manuscript is a part of M.Sc. dissertation prepared by M.L.H. and supervised by C.B., submitted to the University of Bayreuth, Germany, for the partial fulfillment of M.Sc. degree Global Change Ecology.

\section{Authors' information}

M.L. Hossain is currently pursuing Ph.D. in the Department of Geography at Hong Kong Baptist University, Hong Kong. M.L.H obtained M.Sc. in Global Change Ecology from the University of Bayreuth, Germany. He achieved his B.Sc. and M.Sc. in Environmental Science from the University of Chittagong, Bangladesh. He works as a Lecturer (on study leave from 2018 to 2021) in the Department of Environmental Protection Technology, German University Bangladesh, Gazipur, Bangladesh. C. Beierkuhnlein is the Chair of Biogeography, and Head of the graduate program (M.Sc.) "Global Change Ecology" (within the Elite Network of Bavaria), University of Bayreuth, Germany. During 2005-2007, C.B. was the Dean of the Faculty of Biology, Chemistry and Geosciences, University of Bayreuth, Germany. He is a member of the editorial board of Basic and Applied Ecology and Journal of Applied Vegetation Science.

\section{Ethics approval and consent to participate}

Not applicable.

\section{Competing interests}

The authors declare that they have no competing interests.

\section{Publisher's Note}

Springer Nature remains neutral with regard to jurisdictional claims in published maps and institutional affiliations.

\section{Author details}

${ }^{1}$ Department of Geography, Hong Kong Baptist University, 15 Baptist University Road, Kowloon Tong, Hong Kong. ${ }^{2}$ Global Change Ecology, International Elite Study Programme, Faculty of Biology, Chemistry and Earth Sciences, University of Bayreuth, Universitätsstraße 30, 95440 Bayreuth, Germany. ${ }^{3}$ Department of Environmental Protection Technology, German University Bangladesh, Gazipur 1702, Bangladesh. ${ }^{4}$ Department of Biogeography, University of Bayreuth, Universitätsstraße 30, 95440 Bayreuth, Germany.
Received: 19 September 2018 Accepted: 18 November 2018

Published online: 12 December 2018

\section{References}

Asseng S, Ritchie JT, Smucker AJM, Robertson MJ (1998) Root growth and water uptake during water deficit and recovering in wheat. Plant Soil 201:265-273. https://doi.org/10.1023/A:1004317523264.

Backhaus S, Kreyling J, Grant K, Beierkuhnlein C, Walter J, Jentsch A (2014) Recurrent mild drought events increase resistance toward extreme drought stress. Ecosys 17(6):1068-1081. https://doi.org/10.1007/s10021-014-9781-5.

Beierkuhnlein C, Thiel D, Jentsch A, Willner E, Kreyling J (2011) Ecotypes of European grass species respond differently to warming and extreme drought. J Ecol 99:703-713. https://doi.org/10.1111/j.1365-2745.2011.01809.x.

Bloor JMG, Pichon P, Falcimagne R, Leadley P, Soussana JF (2010) Effects of warming, summer drought, and $\mathrm{CO}_{2}$ enrichment on aboveground biomass production, flowering phenology and community structure in an upland grassland ecosystem. Ecosys 13:888-900. https://doi.org/10.1007/s10021-0109363-0.

Butof A, von Riedmatten L, Dormann CF, Lorenzen S, Welk E, Bruelheide H (2012) The response of grassland plants to experimentally simulated climate change depend on land use and region. Glob Chang Biol 18:127-137. https://doi. org/10.1111/j.1365-2486.2011.02539.x.

Chelli S, Canullo R, Campetella G, Schmitt AO, Bartha S, Cervellini M, Wellstein C (2016) The response of sub-Mediterranean grasslands to rainfall variation is influenced by early season precipitation. Appl Veg Sci 19:611-619. https:// doi.org/10.1111/avsc.12247.

Chen J, Luo Y, Xia J, Wilcox KR, Cao J et al (2017) Warming effects on ecosystem carbon fluxes are modulated by plant functional types. Ecosyst 20:515-526. https://doi.org/10.1007/s10021-016-0035-6.

Crafts-Brandner SJ, Salvucci ME (2002) Sensitivity of photosynthesis in a C4 plant, maize, to heat stress. Pla Physi 129:1773-1780. https://doi.org/10.1104/pp. 002170.

Craine JM, Nippert JB, Elmore AJ, Skibbe AM, Hutchinson SL (2012) Timing of climate variability and grassland productivity. PNAS 109(9):3401-3405. https:// doi.org/10.1073/pnas.1118438109.

Dahlström A, luga AM, Lennartsson T (2013) Managing biodiversity rich hay meadows in the EU: a comparison of Swedish and Romanian grasslands. Envir Cons 40(2):194-205. https://doi.org/10.1017/S0376892912000458.

De Boeck HJ, Dreesen FE, Janssens IA, Nijs I (2011) Whole system responses of experimental plant communities to climate extremes imposed in different seasons. N Phyt 189:806-817. https://doi.org/10.1111/j.1469-8137. 2010.03515.x.

Duncan DA, Woodmansee RG (1975) Forecasting forage yield from precipitation in California's annual rangeland. J Ran Manag 28:327-329. https://doi.org/10. 2307/3897788.

Fay PA, Carlisle JD, Knapp AK, Blair JM, Collins SL (2003) Productivity responses to altered rainfall patterns in a C4-dominated grassland. Oecol 137:245-251. https://doi.org/10.1007/s00442-003-1331-3.

García-Feced C, Weissteiner CJ, Baraldi A, Paracchini ML, Maes J, Zulian G, Kempen M, Elbersen B, Pérez-Soba M (2015) Semi-natural vegetation in agricultural land: European map and links to ecosystem service supply. Agronomy for Sustainable Dev 35(1):273-283.

Gargallo-Garriga A, Sardans J, Perez-Trujillo M, Oravec M, Urban O, Jentsch A et al (2015) Warming differentially influences the effects of drought on stoichiometry and metabolomics in shoots and roots. N Phyto 207(3):591603. https://doi.org/10.1111/nph.13377.

Gellesch E, Wellstein C, Beierkuhnlein C, Kreyling J, Walter J, Jentsch A (2015) Plant community composition is a crucial factor for heath performance under precipitation extremes. J Veg Sci:1-10. https://doi.org/10.1111/jvs. 12304

Görgen, K., Beersma, J., Brahmer, G., Buiteveld, H., Carambia, M., de Keizer, O.,..., Volken, D. (2010). Assessment of climate change impacts on discharge in the Rhine Basin. Results of the RheinBlick 2050 Project.

Grant K, Kreyling J, Beierkuhnlein C, Jentsch A (2017) Importance of seasonality for the response of a mesic temperate grassland to increased precipitation variability and warming. Ecosys 20(8):1454-1467. https://doi.org/10.1007/ s10021-017-0122-3.

Grant K, Kreyling J, Dienstbach LFH, Beierkuhnlein C, Jentsch A (2014) Water stress due to increased intra-annual precipitation variability reduced forage yield but raised forage quality of a temperate grassland. Agr, Ecos \& Envir 186:11-22. https://doi.org/10.1016/j.agee.2014.01.013. 
Grime JP (1998) Benefits of plant diversity to ecosystems: immediate, filter and founder effects. J Ecol 86:902-910. https://doi.org/10.1046/j.1365-2745.1998. 00306.x.

Grime JP, Brown VK, Thompson K, Masters GJ, Hillier SH, Clarke IP et al (2000) The response of two contrasting limestone grasslands to simulated climate change. Scien 289:762-765. https://doi.org/10.1126/science.289.5480.762.

Guo L, Chen J, Luedeling E, He J-S, Cheng J, Wen Z, Peng C (2018) Early-spring soil warming partially offsets the enhancement of alpine grassland aboveground productivity induced by warmer growing seasons on the Qinghai-Tibetan Plateau. Plant Soil 425:177. https://doi.org/10.1007/s11104018-3582-0.

Hector A, Schmid B, Beierkuhnlein C, Caldeira MC, Diemer M, Dimitrakopoulos PG et al (1999) Plant diversity and productivity experiments in European grasslands. Scien 286:1123-1127. https://doi. org/10.1126/science.286.5442.1123.

Huston MA, Aarssen LW, Austin MP, Cade BS, Fridley JD, Garnier E et al (2000) No consistent effect of plant diversity on productivity. Scien 289:1255a. https:// doi.org/10.1126/science.289.5483.1255a.

Huxman TE, Smith MD, Fay PA, Knapp AK, Shaw MR, Loik ME et al (2004) Convergence across biomes to a common rain-use efficiency. Natu 429:651654. https://doi.org/10.1038/nature02561.

IPCC. Climate Change (2007): The physical science basis. Contribution of working group I to the fourth assessment report of the intergovernmental panel on climate change. Cambridge \& New York, p. 996

Isbell F, Craven D, Connolly J, Loreau M, Schmid B, Beierkuhnlein C et al (2015) Biodiversity increases the resistance of ecosystem productivity to climate extremes. Natu 526:574-577. https://doi.org/10.1038/nature15374.

Jentsch A, Kreyling J, Apostolova I, Bahn M, Bartha S, Beierkuhnlein C et al (2014) Joining biodiversity experiments, climate change research and invasion biology to assess European gradients of grassland resilience in the face of climate extremes. In: Mucina L, Price JN, Kalwij JM (eds) Biodiversity and vegetation: patterns, processes, conservation. Kwongan Foundation, Perth, p 114.

Jentsch A, Kreyling J, Beierkuhnlein C (2007) A new generation of climate change experiments: events, not trends. Fron Ecol Envir 5:365-374. https://doi.org/10. 1890/1540-9295(2007)5[365:ANGOCE]2.0.CO;2

Jentsch A, Kreyling J, Elmer M, Gellesch E, Glaser B, Grant K et al (2011) Climate extremes initiate ecosystem regulating functions while maintaining productivity. J Ecol 99:689-702. https://doi.org/10.1111/j.1365-2745.2011. 01817.x.

Kahmen A, Perner J, Buchmann N (2005) Diversity dependent productivity in semi-natural grasslands following climate perturbations. FuncEcol 19:594601. https://doi.org/10.1111/j.1365-2435.2005.01001.x.

Kakani VG, Surabhi GK, Reddy KR (2008) Photosynthesis and fluorescence responses of C4 plant Andropogongerardii acclimated to temperature and carbon dioxide. Photosyn 46:420-430. https://doi.org/10.1007/s11099-0080074-0

Knapp AK, Beier C, Briske DD, Classen AT, Luo Y, Reichstein M et al (2008) Consequences of more extreme precipitation regimes for terrestrial ecosystems. Biosci 58(9):811-821. https://doi.org/10.1641/B580908.

Kreyling J, Jentsch A, Beierkuhnlein C (2011a) Stochastic trajectories of succession initiated by extreme climate events. Ecol Lett 14:758-764. https://doi.org/10. 1111/j.1461-0248.2011.01637.x

Kreyling J, Jurasinski G, Grant K, Retzer V, Jentsch A, Beierkuhnlein C (2011b) Winter warming pulses affect the development of planted temperate grassland and dwarf-shrub heath communities. PlaEcol Diver 4:13-21. https:// doi.org/10.1080/17550874.2011.558125.

La Pierre KJ, Blumenthal DM, Brown CS, Klein JA, Smith MD (2016) Drivers of variation in aboveground net primary productivity and plant community composition differ across a broad precipitation gradient. Ecosys 19(3):521533. https://doi.org/10.1007/s10021-015-9949-7.

Lauenroth WK, Sala OE (1992) Long-term forage production of North American shortgrass steppe. EcoloAppli 2(4):397-403. https://doi.org/10.2307/1941874

Lieth H (1975) In: Lieth H, Whittaker RH (eds) Primary productivity of the biosphere. Springer, New York, pp 237-263.

Ludewig K, Donath TW, Zelle B, Kckstein RL, Mosner E, Otte A, Jensen K (2015) Effects of reduced summer precipitation on productivity and forage quality of floodplain meadows at the Elbe and the Rhine River. PLoS One 10(5): e0124140. https://doi.org/10.1371/journal.pone.0124140.
Ma Z, Liu H, Mi Z, Zhang Z, Wang Y, Xu W et al (2017) Climate warming reduces the temporal stability of plant community biomass production. Nat Commun 8(15378):1-7. https://doi.org/10.1038/ncomms15378.

Malyshev AV, Khan MASA, Beierkuhnlein C, Steinbauer MJ, Henry HAL, Jentsch A et al (2015) Plant responses to climatic extremes: within-species variation equals among-species variation. Glob Chang Biol 22(1):449-464. https://doi. org/10.1111/gcb.13114

McLaren JR, Turkington R (2010) Ecosystem properties determined by plant functional group identity. J Ecol 98:459-469. https://doi.org/10.1111/j.13652745.2009.01630.x.

Morecroft MD, Masters GJ, Brown VK, Clarke IP, Taylor ME, Whitehouse AT (2004) Changing precipitation patterns alter plant community dynamics and succession in an ex-arrable grassland. Funct Ecol 18:648-655. https://doi.org/ 10.1111/j.0269-8463.2004.00896.x.

Reichstein, M., Ciais, P., Papale, D., Valentini, R., Running, S., Viovy, N., ... \& Zhao, M. (2006). Reduction of ecosystem productivity and respiration during the European summer 2003 climate anomaly: a joint flux tower, remote sensing and modeling analysis. Glob Chang Biol, 13(3), 634-651. https://doi.org/10. 1111/j.1365-2486.2006.01224.x.

Ru J, Zhou Y, Hui D, Zheng M, Wan S (2018) Shift of growing-season precipitation peaks decrease soil respiration in a semiarid grassland. Glob Chang Biol 24(3):1001-1011. https://doi.org/10.1111/gcb.13941.

Sage RF, Kubien DS (2007) The temperature response of $C_{3}$ and $C_{4}$ photosynthesis. Plan Cel Environ 30:1086-1106. https://doi.org/10.1111/j. 1365-3040.2007.01682.x

Sala OE, Parton WJ, Joyce LA, Lauenroth WK (1988) Primary production of the central grassland region of the United States. Ecol 69:40-45. https://doi.org/ $10.2307 / 1943158$.

Sternberg M, Brown VK, Masters GJ, Clarke IP (1999) Plant community dynamics in a calcareous grassland under climate change manipulations. Pla Ecol 143: 29-37. https://doi.org/10.1023/A:1009812024996.

Suttle KB, Thomsen MA, Power ME (2007) Species interactions reverse grassland responses to changing climate. Scien 315:640-642. https://doi.org/10.1126/ science.1136401.

Tilman D, Downing JA (1994) Biodiversity and stability in grasslands. Natur 367: 363-365. https://doi.org/10.1038/367363a0.

Tilman D, Reich PB, Knops J, Wedin D, Mielke T, Lehman C (2001) Diversity and productivity in a long-term grassland experiment. Scien 294:843-845. https:// doi.org/10.1126/science.1060391.

Urbina I, Sardans J, Beierkuhnlein C, Jentsch C, Backhaus S, Grant S, Kreyling J, Peñuelas J (2014) Shifts in the elemental composition of plants during a very severe drought. Envir Exper Bot 111:63-73. https://doi.org/10.1016/j. envexpbot.2014.10.005.

Veen P, Jefferson R, de Smidt J, van der Straaten J (eds) (2009) Grasslands in Europe of high nature value. KKNV publishing, Den Haag.

Walter J, Grant K, Beierkuhnlein C, Kreyling J, Weber M, Jentsch A (2012) Increased rainfall variability reduces biomass and forage quality of temperate grassland largely independent of mowing frequency. Agri, Ecosys Envir 148: 1-10. https://doi.org/10.1016/j.agee.2011.11.015.

Wang Y, Yu S, Wang J (2007) Biomass-dependent susceptibility to drought in experimental grassland communities. Ecol Lett 10:401-410. https://doi.org/10. 1111/j.1461-0248.2007.01031.x.

Webb WL, Lauenroth WK, Szarek SR, Kinerson RS (1986) Primary production and abiotic controls in forests, grasslands, and desert ecosystems of the United States. Ecol 64:134-151. https://doi.org/10.2307/1937336.

Weißhuhn K, Auge H, Prati D (2011) Geographic variation in the response to drought in nine grassland species. Bas App Ecol 12:21-28. https://doi.org/10. 1016/j.baae.2010.11.005

Zavaleta SE, Shaw MR, Chiariello NR, Thomas BD, Cleland EE, Field CB, Mooney HA (2003) Grassland responses to three years of elevated temperature, CO2, precipitation, and N deposition. Ecolog Monog 73:585-604. https://doi.org/ 10.1073/pnas.0932734100 